\title{
Keratoconus prediction using a finite element model of the cornea with local biomechanical properties
}

\author{
Propriedades biomecânicas locais em uma córnea modelada usando elementos \\ finitos prevê surgimento de ceratocone
}

\author{
Luis Alberto Carvalho' \\ Marcelo Prado 2 \\ RodivaldoH.Cunha ${ }^{3}$ \\ Alvaro Costa Neto ${ }^{4}$ \\ Augusto Paranhos Jr. ${ }^{5}$ \\ PauloSchor ${ }^{6}$ \\ Wallace Chamon ${ }^{7}$
}

\begin{tabular}{l} 
ABSTRACT \\
\hline Purpose: The ability to predict and understand which biomechanical \\
properties of the cornea are responsible for the stability or progression \\
of keratoconus may be an important clinical and surgical tool for the eye- \\
care professional. We have developed a finite element model of the \\
cornea, that tries to predicts keratoconus-like behavior and its evolution \\
based on material properties of the corneal tissue. Methods: Corneal \\
material properties were modeled using bibliographic data and corneal \\
topography was based on literature values from a schematic eye model. \\
Commercial software was used to simulate mechanical and surface \\
properties when the cornea was subject to different local parameters, \\
such as elasticity. Results: The simulation has shown that, depending \\
on the corneal initial surface shape, changes in local material properties \\
and also different intraocular pressures values induce a localized pro- \\
tuberance and increase in curvature when compared to the remaining \\
portion of the cornea. Conclusions: This technique provides a quantitative \\
and accurate approach to the problem of understanding the biomechanical \\
nature of keratoconus. The implemented model has shown that changes \\
in local material properties of the cornea and intraocular pressure are \\
intrinsically related to keratoconus pathology and its shape/curvature.
\end{tabular}

Keywords: Cornea/anatomy \& histology; Biomechanics; Corneal topography/instrumentation; Keratoconus; Refractive errors/diagnosis; Image processing, computer-assisted; Intraocular pressure

\section{INTRODUCTION}

In recent years there has been an increasing number of researchers and companies interested in understanding long- and short-term responses of the cornea when subject to different physical conditions. We think this has happen mainly due to the refractive surgery field. The development of better and more efficient excimer lasers (such as the flying spot lasers ${ }^{(1-3)}$ ) and more precise techniques for measuring cornea and whole eye aberrations (such as the Hartman-Shack wavefront sensor ${ }^{(4-10)}$ or the cylindrical sensor introduced by our research group $\left.{ }^{(11-13)}\right)$ allowed for the development of better ablation algorithms and, ultimately, customized methods. Nevertheless, there has been a considerable amount of frustration regarding results obtained with recent algorithms for certain keratoconus suspicious cases. This in turn raised questions regarding the correctness or incorrectness of treating the cornea as if it behaved similar to materials such as plastic $^{(14-15)}$. Today it is well known that the corneal tissue is much more dynamic and complex than polymers and certainly cannot be treated as a 
static element. The necessity to understand increasingly more complex behaviors and properties of the cornea induced, in turn, the application of more sophisticated algorithms and corneal mathematical models. Most research groups today agree that the best approach is to use a technique known as finite element $(\mathrm{FE})$ model $^{(16)}$ and most of them have recently used sophisticated FE commercial software packages to study responses to refractive surgery ${ }^{(14)}$, corneal transplant (keratoplasty $)^{(17)}$, intrastromal ring implant ${ }^{(18)}$, implants of intraocular lens (IOL) ${ }^{(19)}$, among other procedures.

Although many types of refractive surgeries have been modeled using these sophisticated FE methods, little attention has been given to the study of keratoconus using these same techniques. To our knowledge, there is no biomechanical model available that satisfactorily explains the arising, the stability or the evolution of keratoconus. That is, which keratoconus is and will remain incipient, which cases will progress and become critical, and so forth. When cases are difficult and there is chance of ambiguity, it is not uncommon for the eye-care professional to examine close relatives of patients in order to accomplish a more precise diagnosis. Patients with keratoconus are usually unhappy with spectacle corrections due to the manifestation of higher order aberrations ${ }^{(20-21)}$, which are mostly consequence of anterior corneal surface irregularities. Although there are current refractive surgery techniques for customized correction of lower and higher order aberrations ${ }^{(22-23)}$, just to name a few, patients with keratoconus are rarely indicated for any type of refractive surgery. This happens because keratoconus is a pathology that induces differences in biomechanical properties of the cornea, such as elasticity and rigidity. Because of these changes, surgery outcome becomes unpredictable and may be disastrous for the patient, in some cases requiring keratoplasty.

The difficulties in the diagnosis of keratoconus and the possible irreversible consequences that an improper surgical intervention may cause, have stimulated our research group to develop a FE mechanical model of the cornea. We believe this is an important step in order to understand the relationships between biomechanical property changes and the appearance of keratoconus.

\section{METHODS}

\section{Finite element modeling of the cornea}

The FE model developed in this study was based in part on the mathematical model developed by Orssengo and Pye ${ }^{(24)}$. The limbus and a portion of the scleral tissue were also modeled. The limbus and sclera were added to our model because they influence the biomechanical behavior of the cornea. Moreover the fiber orientations on the limbus collagen are different from those of the corneal collagen (Figure 1).

For the modeling in FE of the different portions of the eye, shell membrane elements were chosen. For this type of element

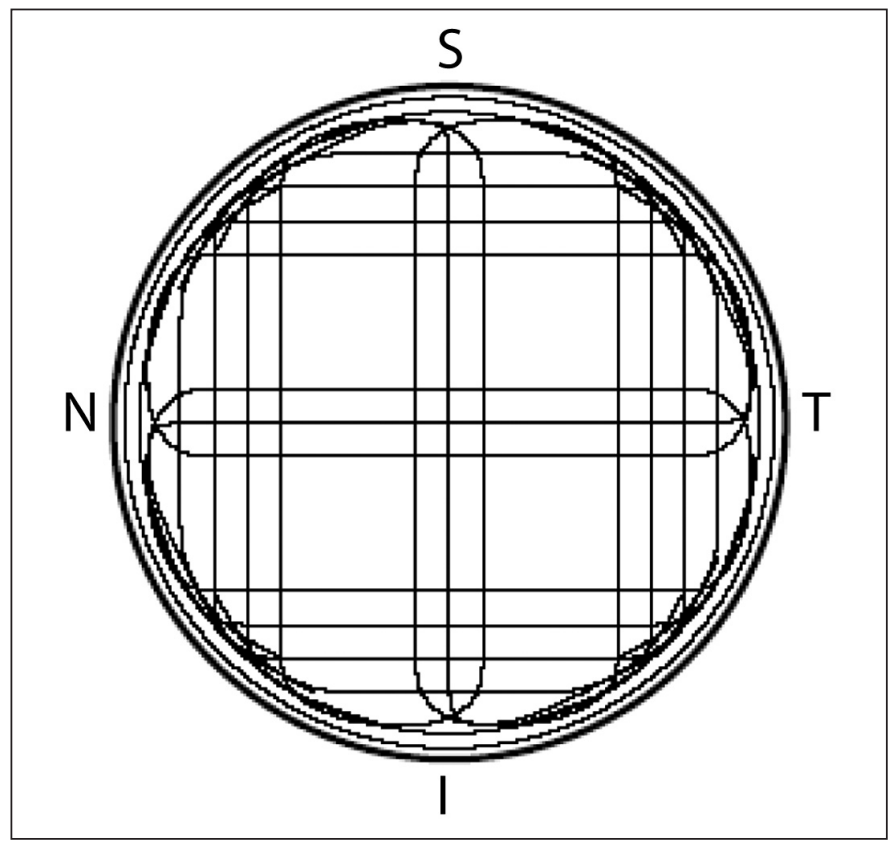

Figure 1 - Collagen fiber orientation on the cornea is meridional and on the limbus it is circumferential

a plane state of tensions is considered because the thickness of the tissue may be considered infinitely small when compared to the other dimensions of the model (Figure 2A).

The meridional force acting on the infinitesimal element $d s$ in figure $2 \mathrm{~B}$ is given by

$$
F_{m}=s_{m} t d s
$$

where $t$ is the thickness of the cornea and $s_{m}$ is the meridional infinitesimal tension per area acting on one side of the infinitesimal element. Because of the curvature of the cornea the two tensions have an angle between them of $d \phi$ and the following relation for $d s$ is valid:

$$
d s=R d \phi
$$

where $\mathrm{R}$ is the radius of curvature.

The resultant of the meridional forces on the walls of the infinitesimal element is given by

$$
\left(s_{m} t d s\right) d \phi=\frac{s_{m} t(d s)^{2}}{R}
$$

And in the same manner, the resulting forces in the tangential direction (or circumferential in this case) is given by

$$
\frac{s_{t} t(d s)^{2}}{R}
$$

The meridional and tangential forces counterbalance the force that arises from eye pressure $\mathrm{p}$ :

$$
\frac{s_{m} t(d s)^{2}}{R}+\frac{s_{t} t(d s)^{2}}{R}=p(d s)^{2}
$$

And rearranging we get: 


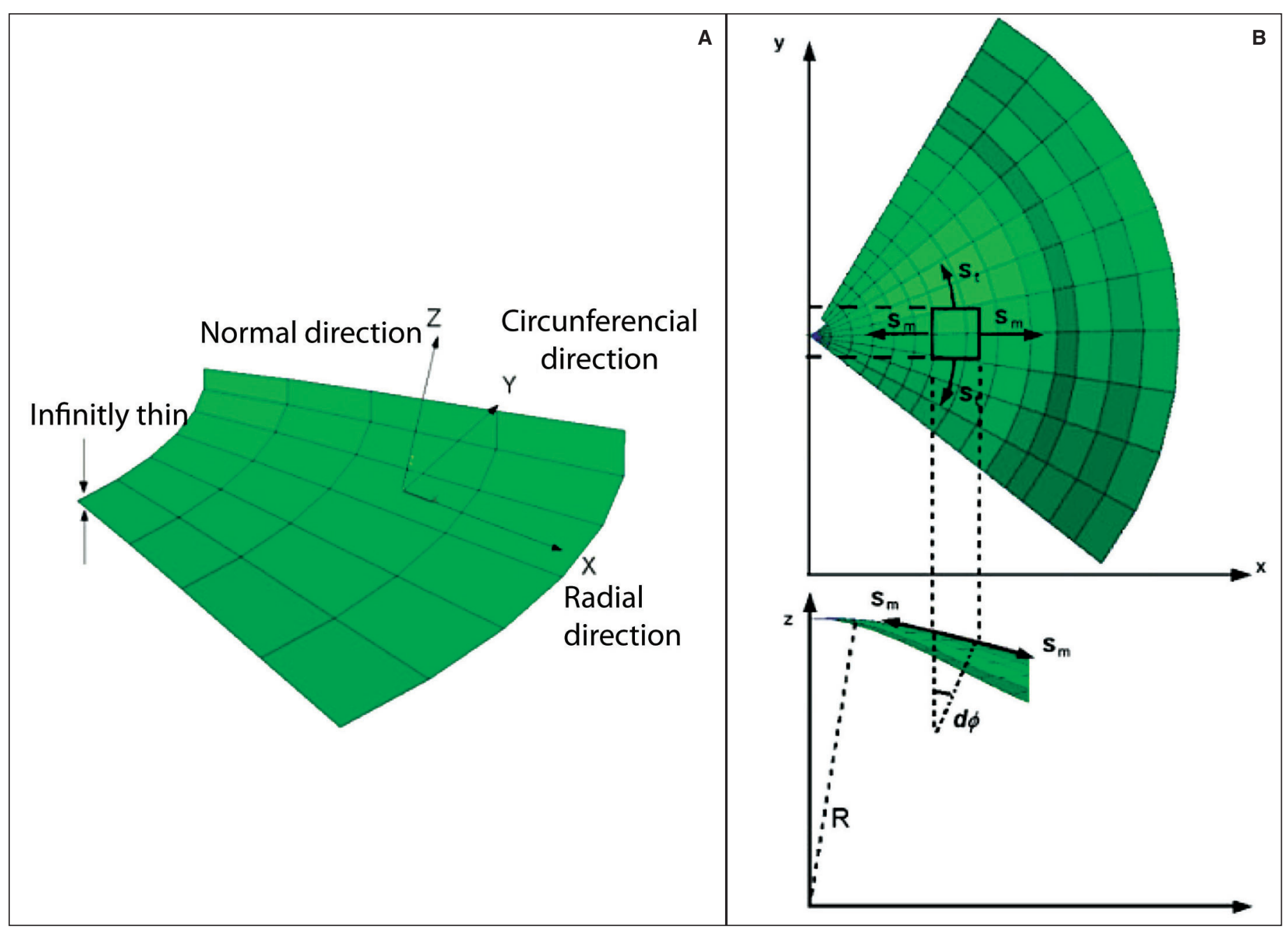

Figure 2 - A) Shell membrane model of the cornea; B) Distribution of forces in the radial and circumferential directions

$$
s_{m}+s_{t}=\frac{p R}{t}
$$

The above equation is derived from the equilibrium condition in the direction normal to the surface, considering tensions $s_{m}$ and $s_{t}$. The shell-type modeling of the cornea using FE was also used by other authors, among them Orssengo and Pye, Shin et al., Uchio et al., Anderson et al. ${ }^{(24-27)}$.

In the models of Orssengo and Pye ${ }^{(24)}$ and Anderson et al. ${ }^{(27)}$ a model of the cornea was implemented with the boundary condition that allows only a $40^{\circ}$ angle of freedom for motion of the limbus region (figure 3$)^{(24)}$.

Orssengo and Pye developed a complete model of the ocular globe. Nevertheless this model is targeted towards the simulation of object impacts on the eye ${ }^{(24)}$. They also developed a complete model of the ocular globe, but in this case the objective was to study the dynamic tonometry (pneumatic tonometry using air jets), where the shock wave propagation through the eye was studied. Figure 4A shows the FE model of cornea limbus and sclera developed here, and figure 4B shows the complete eye. The FE software used in this work

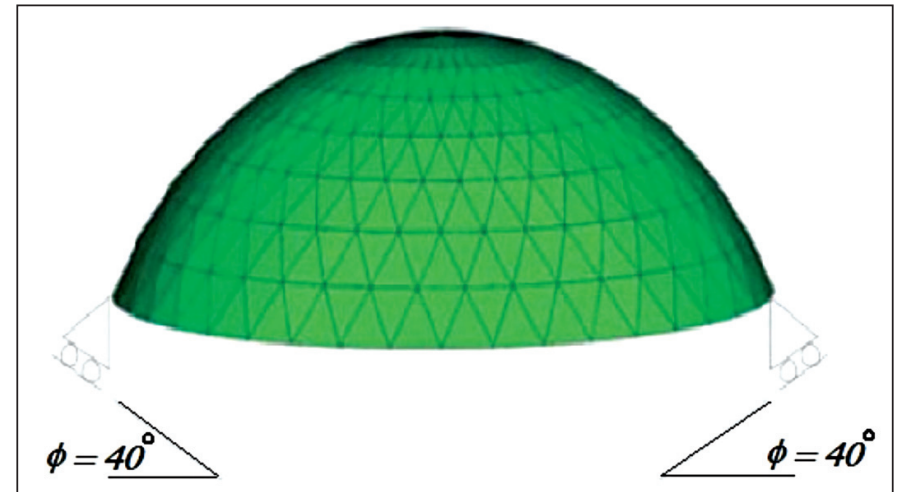

Figure 3 - Boundary condition for the corneal models(24,27)

was MSC Patran (http://www. mscsoftware.com). The geometry of this model was based on the conic equations from the schematic eye of Liou and Brennan ${ }^{(28)}$.

The elasticity in the circumferential direction for our model was based on the same values used by Orssengo and Pye ${ }^{(24)}$. For the other directions on the cornea and for the limbus, we im- 


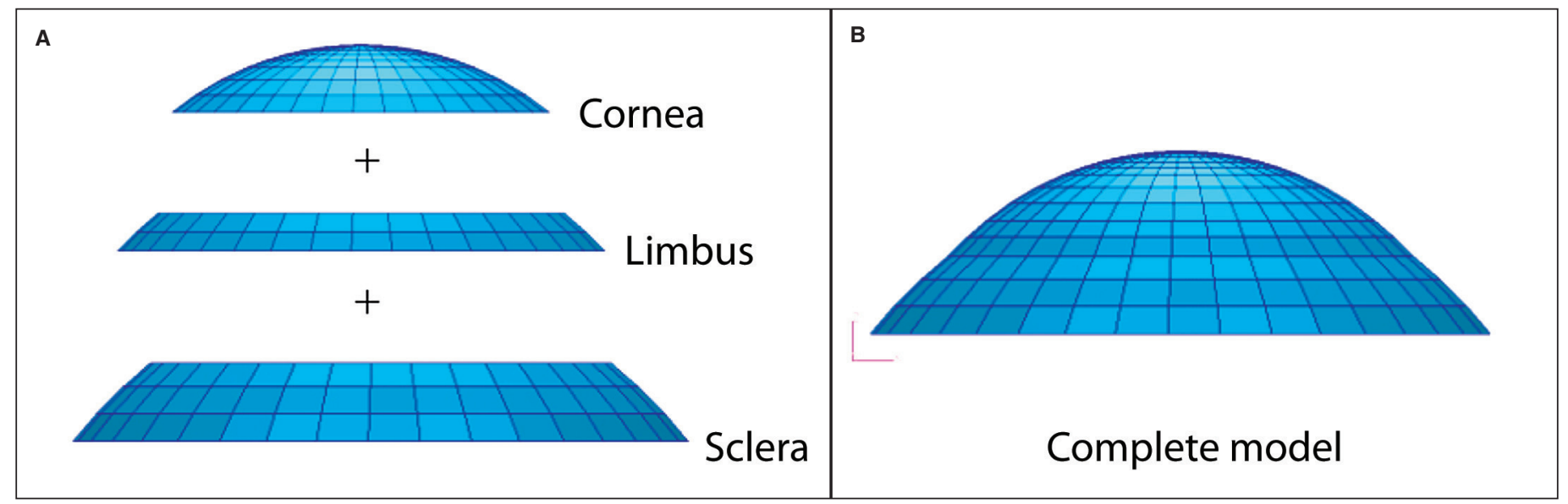

Figure 4 - Finite element model of the eye showing cornea, limbus and sclera

plemented some preliminary studies varying the rigidity between $1 / 4$ and $1 / 6$ of the rigidity in the circumferential direction. With these simulations values for elasticity as a function of intraocular pressure (IOP) were obtained (Table 1), which furnish excellent results regarding tonometric measurements.

For the analysis of the tonometry in the pressure values of $15,20,30$ and $40 \mathrm{mmHg}$, the values of modules of elasticity are $0.34,0.458,0.68$ e $0.92 \mathrm{MPa}$. This variation of the modules of elasticity with the increase in ocular pressure is characteristic of a non-linear material. Regarding the rigidity of the scleral tissue, it is much greater than that of the cornea and limbus. In the present study we used the results from two authors ${ }^{(25-26)}$ to set such parameter. The value of rigidity used for the present study was $10 \mathrm{MPa}$ in the meridional direction and 2.5 $\mathrm{MPa}$ for the other two directions (circumferential and normal).

\section{Keratoconic modeling}

The initial analysis presented here has not been compared with actual data from an in vivo eye, therefore should not be considered a conclusive or definitive model. Moreover, since only a general analysis of shape deformations and tension differences are made, with no comparison to in vivo or "real" data, we can only draw, at this point, qualitative analysis based on here obtained results.

In the keratoconic cornea the lamellae fibers suffer disarrangement and the rigidity of the material in that region decreases considerably ${ }^{(29)}$. Because of this disarrangement the corneal tissue becomes isotropic, i. e, the elasticity module is equal in all directions. In the present study we have modeled a keratoconus as a circular region centered nasally (for a left eye) with different local properties when compared to the remaining corneal tissue (Figure 6).

\section{RESULTS}

After determining all the boundary conditions, the simulation was implemented in our FE modeling software. Figure 7

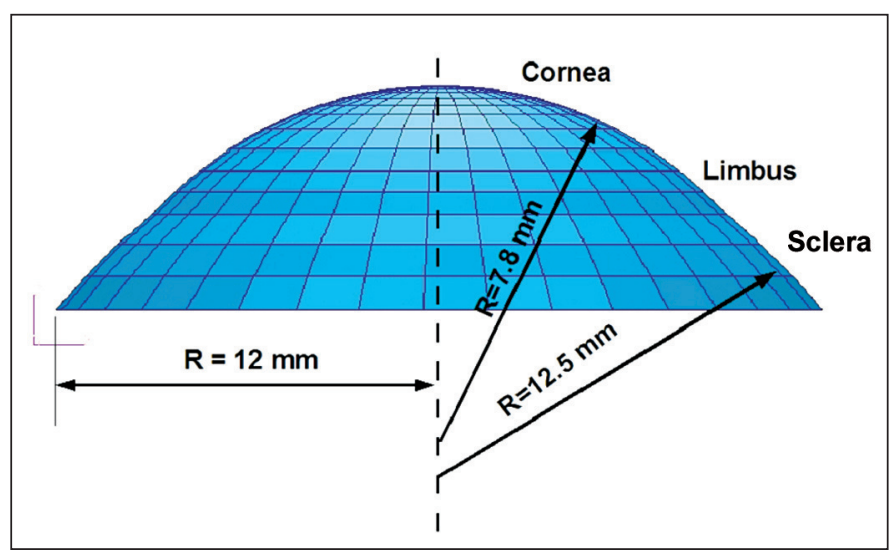

Figure 5 - Geometry of the FE eye model used for the virtual tonometry analysis

\begin{tabular}{|c|c|c|}
\hline Direction & Cornea (MPa) & Limbus (MPa) \\
\hline Radial & $0.00229 \times$ x IOPT & $0.00229 \times$ IOPT/4.8 \\
\hline Circunferencial & $0.00229 \times 10 P T / 4.8$ & $0.00229 \times$ IOPT \\
\hline Normal & $0.00229 \times 10 P T / 4.8$ & $0.00229 \times$ IOPT/4.8 \\
\hline
\end{tabular}

shows the deformation obtained in the vertical $(\mathrm{Z})$ direction. The local protuberance generated by the localized difference in elasticity may be clearly observed.

Figure 8 shows the isometric vertical deformation due to the keratoconic region. Figure 8 is the same plot as in figure 7, with a different viewpoint. The colored scale shows the isometric difference in millimeters for the deformation in the Z-axis.

The distribution of von Mises pressures on the cornea may be seen in Figure 9. The keratoconus considerably altered the tension distribution on the cornea. The interesting aspect to notice is that in the region of the cone the von Mises pressures are smaller. The increase in tension occurred predominantly on the region that surrounds the keratoconus. In this 


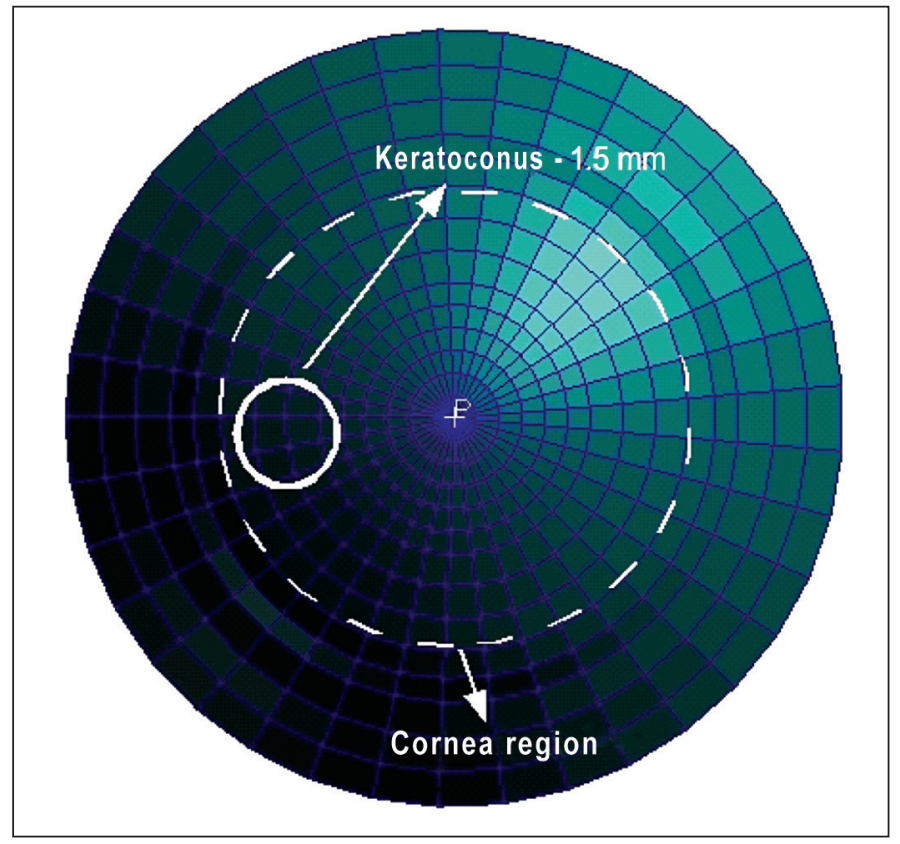

Figure 6 - Keratoconus model for the cornea

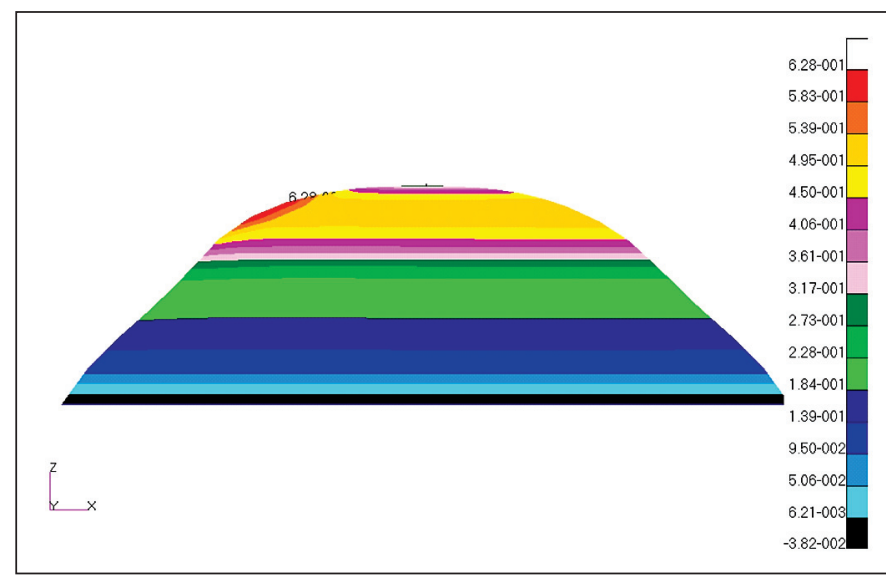

Figure 7 - Lateral view of the deformation in the $\mathrm{Z}$ direction - IOP is maintained at $15 \mathrm{mmHg}$ and scale is in $\mathrm{mm}$

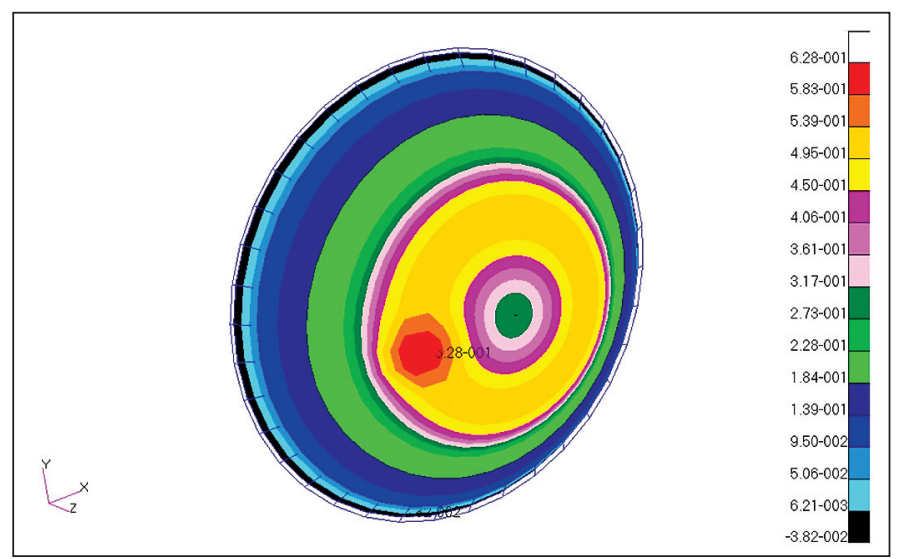

Figure 8 - Isometric view of the deformation in the $Z$ direction of the keratoconic cornea with IOP of $15 \mathrm{mmHg}$ surrounding region there is a significant change in shape of the cornea that causes an increase in pressure. In the central area of the keratoconus the tension remained low. The isotropic properties and the smaller values of elasticity also contributed to the decrease in tensions in this region.

The keratoconus region significantly altered the distribution of tension over the cornea. It is interesting to notice that the surface tensions over the keratoconus are smaller than in the surrounding areas (Figure 10). Tensions increased in the region of transition from non-keratoconic to keratoconic. In the center of the keratoconus the surface tension remained small. The isotropic properties and the smaller Young modules in this region can explain this behavior

Another important analysis, at least qualitatively, is how these changes in tension and surface elevation affect curvature. For that we have computed axial dioptric power (proportional to curvature) of the keratoconic surface. The color-

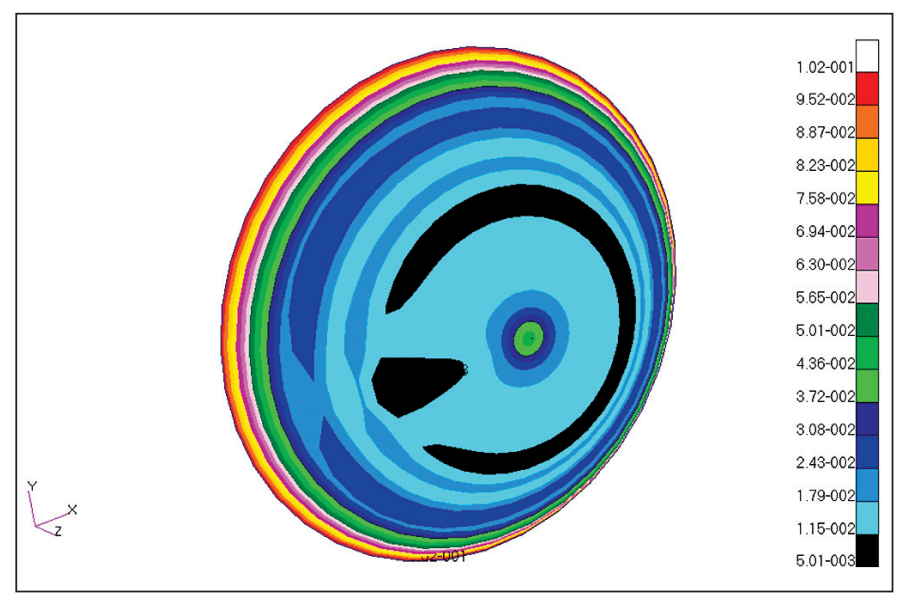

Figure 9 - von Mises tension distribution on the keratoconic cornea

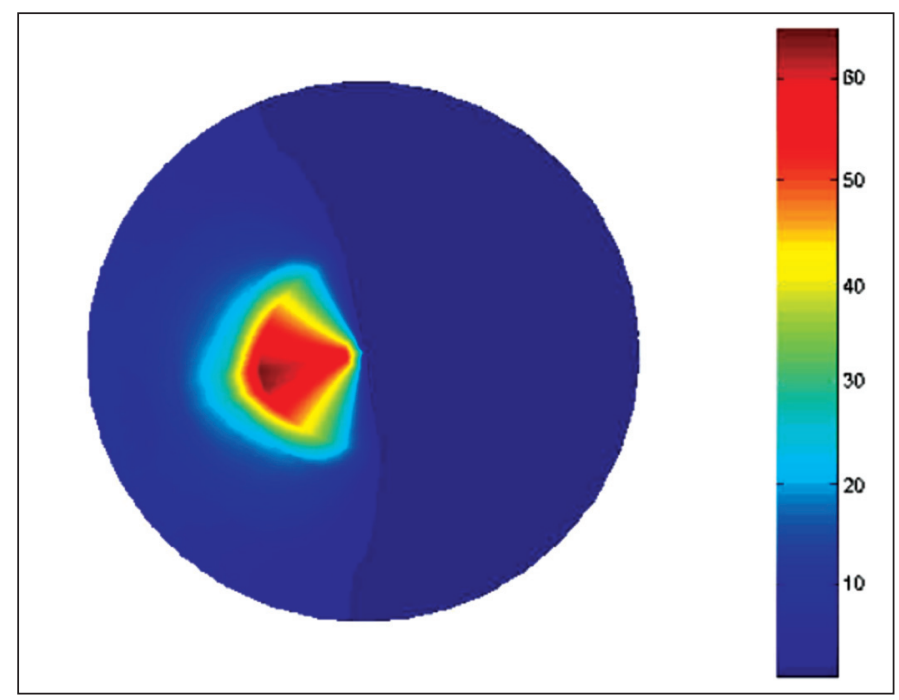

Figure 10 - Dioptric power (proportional to curvature) map of the simulated keratoconic cornea. Resemblance with conventional videokeratography maps is evident. 
coded topographic map, similar to a videokeratography output, may be seen in figure 10. Resemblance with an in vivo keratoconic topography map is evident.

\section{CONCLUSION}

This initial analysis, although qualitative in the sense that no comparison was undertaken with in vivo data, shows quantitative values that indicate that the FE model constructed here may be a useful tool in the near future for better understanding biomechanical properties of keratoconus and its evolution. The model implemented here has shown that changes in local material properties of the cornea (such as elasticity and rigidity), at a constant and normal IOP, are intrinsically related to the keratoconus-like effect and its shape/curvature. Optical and curvature analysis based on our keratoconic corneal surfaces has yet to be implemented. The initial analysis presented here has not been compared to in vivo and statistically significant data and therefore should not be considered a conclusive or definitive biomechanical model of keratoconus.

\section{RESUMO}

Objetivos: A possibilidade de prever e entender quais propriedades biomecânicas da córnea podem ser responsáveis pelo progresso ou estabilização do ceratocone pode ser uma importante ferramenta clínica e cirúrgica para o oftalmologista. Neste trabalho foi desenvolvido um modelo em elementos finitos da córnea, o qual prevê o surgimento de deformações semelhantes ao ceratocone e sua evolução baseado em propriedades biomecânicas do tecido corneano. Métodos: As propriedades biomecânicas da córnea foram modeladas segundo dados disponíveis na literatura para olhos esquemáticos. Softwares comerciais foram usados para simular propriedades de superfície e material quando a córnea foi submetida a diferentes parâmetros locais de elasticidade. Resultados: As simulações conduzidas aqui mostraram que, dependendo do formato inicial da córnea, mudanças nas propriedades locais do material para diferentes pressões intraoculares, induzem uma protuberância localizada e um aumento significativo de curvatura quando comparado ao restante da córnea. Conclusões: A técnica apresentada aqui permite o estudo mais preciso e quantitativo da natureza biomecânica do ceratocone. O modelo implementado demonstrou que mudanças locais de propriedades biomecânicas relacionais à elasticidade para uma mesma pressão intraocular, estão intrinsecamente relacionados ao surgimento e evolução de deformações que podem ter relação direta com o ceratocone.

Descritores: Córnea/anatomia e histologia; Biomecânica; Topografia da córnea/instrumentação; Ceratocone; Erros de refração/diagnóstico; Processamento de imagem assistida por computador; Pressão intraocular

\section{REFERENCES}

1. Nagy ZZ, Szabo V, Takacs A, Suveges I. [Results of photorefractive keratectomy in myopia with flying spot excimer laser with high speed and small beam diameter]. Orv Hetil. 2005;146(6):253-7. Hungarian.

2. Pettit GH. The ideal excimer beam for refractive surgery. J Refract Surg. 2006; 22(9):S969-72.

3. Stojanovic A, Nitter TA. $200 \mathrm{~Hz}$ flying-spot technology of the LaserSight LSX excimer laser in the treatment of myopic astigmatism: six and 12 month outcomes of laser in situ keratomileusis and photorefractive keratectomy. J Cataract Refract Surg. 2001;27(8):1263-77.

4. Thibos LN. Principles of Hartmann-Shack aberrometry. J Refract Surg. 2000; 16(5):S563-5.

5. Hartmann J. Bemerkungen uber den bau und Die Justirung von Spektrographen. Zt Instrumentenkd. 1900;20:47.

6. Shack RV, Platt BC. Production and use of a lenticular Hartmann screen. J Otp So Am. 1971;61:656.

7. Liang J, Grimm B, Goelz S, Bille JF. Objective measurement of wave aberrations of the human eye with the use of a Hartmann-Shack wavefront sensor. J Opt Soc Am A Opt Image Sci Vis. 1994;11(7):1949-57.

8. Liang J. A new method to preciselly the wave aberration of the human eye with the Hartamann-Shack wavefront sensor [Dissertation]. Heidelberg: University of Heidelberg; 1991.

9. Carvalho LA. A simple and effective algorithm for detection of arbitrary HartmannShack patterns. J Biomed Inform. 2004;37(1):1-9.

10. Carvalho LA, Castro JC, Carvalho LA. Measuring higher order optical aberrations of the human eye: techniques and applications, Braz J Med Biol Res. 2002;35(11):1395-406

11. Carvalho LA, Castro JC. The placido wavefront sensor and preliminary measurement on a mechanical eye. Optom Vis Sci. 2006;83(2):108-18.

12. Carvalho LA, Chamon W, Schor P, Castro JC. Quantitative comparison of different-shaped wavefront sensors and preliminary results for defocus aberrations on a mechanical eye. Arq Bras Oftalmol. 2006;69(2):239-47.

13. Carvalho LA, Castro JC, Chamon W, Schor P. A new wavefront sensor with polar symmetry: quantitative comparison with the Shack-Hartmann wavefront sensor. J Refract Surg. 2006;22(9): 954-8.

14. Roberts C. Biomechanics of the cornea and wavefront-guided laser refractive surgery. J Refract Surg. 2002;18(5):S589-92.

15. Roberts C. The cornea is not a piece of plastic. J Refract Surg. 2000;16(4): 407-7;13. Comment in: J Refract Surg. 2001;17(1):76-7; author reply 77-78; J Refract Surg. 2001;17(1):76; author reply 77-8; J Refract Surg. 2001;17(1): 76; author reply 77-8.

16. Reddy JN. An introduction to the finite element method. $3^{\text {th }}$ ed. Columbus, Ohio: McGraw-Hill; 2005.

17. Cabrera Fernandez D, Niazy AM, Kurtz RM, Djotyan GP, Juhasz T Biomechanical model of corneal transplantation J Refract Surg. 2006;22(3): 293-302.

18. Fleming JF, Wan WL, Schanzlin DJ. The theory of corneal curvature change with the intrastromal corneal ring. CLAO J. 1989;15(2):146-50.

19. McLeod SD, Vargas LG, Portney V, Ting A. Synchrony dual-optic accommodating intraocular lens. Part 1: optical and biomechanical principles and design considerations. J Cataract Refract Surg. 2007;33(1):37-46. Comment in: J Cataract Refract Surg. 2008;34(1):8-9; author reply 9.

20. Sabesan R, Carvalho LA, Jeong TM, Yoon G, Somasundaram R, Cox I. Correcting higher order aberrations using customized soft contact lenses in keratoconic eyes. In: Annual Meeting of the Association for Research in Vision and Ophthalmology (ARVO), 2006 Apr 30- May 4; Fort Lauderdale, EUA. p.57.

21. Sebasan R, Jeong TM, Carvalho LA, Cox I, Williams DR, Yoon G. Vision improvement by correcting higher order aberrations with customized soft contact lenses in keratoconic eyes. Op Lett. 2007;32(8):1000-2.

22. Awwad ST, Bowman RW, Cavanagh HD, McCulley JP. Wavefront-guided LASIK for myopia using the LADAR CustomCornea and the VISX CustomVue. J Refract Surg. 2007;23(1):26-38.

23. Carones F, Vigo L, Scandola E. Wavefront-guided treatment of symptomatic eyes using the LADAR6000 excimer laser. J Refract Surg. 2006;22(9):S983-9.

24. Orssengo GJ, Pye DC. Determination of the true intraocular pressure and modules of elasticity of the human cornea in vivo. Bull Math Biol. 1999;61(3):551-72.

25. Shin TJ, Vito RP, Johnson LW, McCarey BE. The distribution of strain in the human cornea. J Biomech. 1997;30(5):497-503.

26. Uchio E, Ohno S, Kudoh J, Aoki K, Kisielewicz LT. Simulation model of an eyeball based on finite element analysis on a supercomputer. $\mathrm{Br} \mathrm{J}$ Ophthalmol. 1999;83(10):1106-11. Comment in: Br J Ophthalmol. 1999;83(10):1101-2. 
27. Anderson K, El-Sheikh A, Newson T. Application of structural analysis to the mechanical behaviour of the cornea. J R Soc Interface. 2004;1(1):3-15.

28. Liou HL, Brennan NA. Anatomically accurate, finite model eye for optical modeling. J Opt Soc Am A Opt Image Sci Vis. 1997;14(8):1684-95.
29. Pandolfi A, Manganiello F. A model for the human cornea: constitutive formulation and numerical analysis. Biomechan Model Mechanobiol [Internet]. 2006 [cited 2005 Sept 15];5:237-46. Available from: http://www.stru.polimi.it/people/ pandolfi/WebPage/j-2006-corneamaterial.pdf 